\title{
A criatividade da língua portuguesa: estudo de moçambicanismos no português de Moçambique
}

\author{
Rajabo Alfredo Mugabo Abdula
}

Universidade Estadual Paulista Júlio de Mesquita Filho (UNESP)

\section{Considerações iniciais}

Moçambique foi colônia portuguesa; os portugueses chegaram ao país no século XV, concretamente no ano de 1498, quando Vasco da Gama e sua expedição chegaram ao território que hoje se chama Moçambique, marcando, assim, o início de um longo período de colonização que durou cerca de quinhentos anos, como afirma Gonçalves (2000, p. 1): “A chegada dos primeiros portugueses a Moçambique data de finais do século XV: 1498 é o ano da chegada de Vasco da Gama a Moçambique, podendo dizer-se que, a partir desta data, estão lançadas as bases histórico-sociais para o uso do Português nesta região do globo".

Depois de vários anos de colonização, Moçambique tornou-se independente em 1975. Com a conquista da independência, vários desafios o país tinha pela frente; um deles era a educação. A Língua Portuguesa (LP) foi adotada como língua oficial do país; precisava-se estender o acesso à educação para os diversos cantos do país, ou seja, havia necessidade de se fazer com a maior brevidade possível aquilo que o colono não foi capaz de fazer durante quinhentos anos. Para tal, era necessário ter uma educação abrangente que alcançasse os mais diferentes pontos do país, o que culminou com a política de massificação do ensino verificada nos anos iniciais depois da independência.

Por causa da diversidade linguística do país e pela necessidade de dar educação ao moçambicano, definiu-se que a única língua que reunia condição para que esse objetivo fosse alcançado era o português - aliás, o português gozava desse papel mesmo durante o período da luta pela independência do país. Namburete (2006) considera que foi durante a luta de libertação que a FRELIMO ${ }^{1}$ resolveu que, no meio das tantas línguas faladas em Moçambique, o português seria aquela usada para a comunicação entre os combatentes. Vários são os argumentos dados

1. Frente de Libertação de Moçambique. Movimento que lutou pela independência de Moçambique e veio a conquistar em Junho de 1975. 
para esta decisão, incluindo o de que esta seria uma língua "neutra" para servir aos objetivos da luta, sobretudo o de que banindo as outras línguas moçambicanas nas comunicações entre os guerrilheiros combater-se-ia e materializar-se-ia o espírito da unidade nacional quando todos os cidadãos falassem uma só língua. Assim, a LP passou a ser a língua oficial do país e, também, passou a ser a língua de ensino apesar de, na altura, a maior parte da população não falar o português.

Pelo fato de existirem em Moçambique outras línguas fora o português, o contato entre estas línguas é inevitável, pois, elas partilham o mesmo espaço geográfico. Foi o contexto linguístico moçambicano o motivo pelo qual este trabalho foi desenvolvido. Queremos, a partir desse contexto, compreender a seguinte questão: qual é o impacto do contato entre as línguas bantu e o português em Moçambique? Para o efeito, traçamos o seguinte objetivo: identificar as principais áreas de influências das línguas bantu sobre o português. E, como hipóteses, temos: (i) o contato entre o português e as línguas bantu moçambicanas (LBm) fará com que haja influência mútua entre o português e as outras línguas moçambicanas e (ii) teremos casos de moçambicanismos no Português de Moçambique resultantes desse contato.

A metodologia usada para este trabalho foi meramente bibliográfica. Procuramos buscar dados apresentados em trabalhos (livros, teses, artigos) que falam sobre a LP em Moçambique. Autores como Ngunga (2012), Gonçalves (2000, 2012), Dias (2007) e Mendes (2010), só para citar alguns exemplos, foram importantes para o desenvolvimento deste estudo. Em termos de estrutura do capítulo, discutiremos em primeiro lugar sobre a LP no período antes e pós-independência e, de seguida, a identidade linguística no contexto multilíngue. Depois disso, segue uma seção em que se discute neologia e neologismos, onde iremos nos cingir no neologismo fonológico, neologismo sintático e neologismo semântico. De seguida, falaremos sobre empréstimo e estrangeirismo e, mais especificamente, sobre empréstimo de LBm para o português; por último, o foco recai sobre casos de hibridismo, encerrando com as considerações finais.

\section{A Língua Portuguesa no período antes e pós independência}

A história da LP em Moçambique divide-se em dois períodos. O primeiro diz respeito ao período antes da independência que começa com a chegada dos primeiros portugueses a Moçambique e vai até o ano de 1975 e o segundo período (pós-independência) começa em 1975 e vai até os dias de hoje.

No período antes da independência, a LP era falada por um número muito reduzido da população moçambicana e o ensino era quase inexistente. Apenas a minoria da população que era majoritariamente branca tinha acesso a LP e ao 
ensino. De acordo com Gonçalves (2000), em 1890 havia uma única escola primária em todo o país. Esse número deixa claro que o ensino não fazia parte das prioridades da política colonial. Com o andar do tempo, o número de falantes foi crescendo, contudo, deve-se compreender que o aumento de falantes do português durante esse período não foi resultado da difusão da língua para a larga maioria da população; ou seja, não foi traçada uma política de acesso à educação e à língua para a maior parte da população. Na realidade, o aumento de falantes deve-se à política de colonização massiva do território, como avança Gonçalves (2000) ao afirmar que, em 1950, chegaram a Moçambique 50.000 colonos e, em 1960, chegaram mais de 90.000 colonos. Como se pode ver, houve um aumento da população que vinha de Portugal com o intuito de aumentar o domínio sobre o território.

Depois da independência nacional, o cenário mudou; tem-se verificado um crescimento significativo da LP e do número de falantes do português. O número de falantes do idioma oficial no período pós-independência supera o número de falantes em todo o Período colonial (que foi de quase 500 anos). De acordo com Gonçalves (2012, p. 4), esse crescimento “justifica-se pela política educacional depois da independência, e da pré-disposição da população moçambicana em adotar o português como língua de comunicação em detrimento das línguas bantu".

O português foi, portanto, adotado como língua oficial e passou a ser a língua de ensino, apesar da maior parte da população não falar o português no seu dia-a-dia e a LP não ser língua materna para a larga maioria da população, como anteriormente frisamos. Como resultado dessa política adotada pelo Estado moçambicano, em que apenas o português é língua oficial e língua de ensino, cresceu o número de moçambicanos que têm o português como língua materna, principalmente nas zonas urbanas. Com o crescimento da LP nesse país multilingue, é importante estabelecer alguns questionamentos: como é que se encontram as outras línguas? Quais são as políticas traçadas sobre elas para que não desapareçam? Por que elas não são tratadas com o mesmo prestígio que tem a língua portuguesa? Enfim... Essa não é matéria de discussão neste trabalho e não queremos nos cingir nela.

O contato entre a LP, as outras línguas nacionais e as diferentes culturas do país faz com que a língua portuguesa se molde e ganhe novas feições. Assim, o português falado em Moçambique vai criando suas marcas identitárias que o fazem se distinguir do português europeu, por exemplo. É sobre essa identidade que o português ganha no contexto multilingue que iremos nos deter no próximo tópico. 


\section{Identidade linguística no contexto multilíngue}

Devido à situação multilíngue do país, o contacto entre as línguas é constante. Estamos na situação em que o português é a língua oficial do país, língua de ensino, o que faz desta língua a mais prestigiada de todas as línguas do país. Silva Neto (1988, p. 39) considera que "numa situação de contacto de línguas, a língua de prestígio está sujeita a várias mudanças." Essa vulnerabilidade que a língua de prestígio sofre deve-se ao fato de o seu uso ser, em muitos casos, inevitável pelos falantes, mesmo não sendo a língua majoritária, motivada pela função que ela desempenha no país. Sendo o português a língua prestigiada e a única língua oficial para o caso de Moçambique, ela sofre influência das outras línguas pelo simples fato de esta não ser a língua mais usada no dia-a-dia por uma parte de moçambicanos. Essa situação linguística cria condições para que haja contacto frequente entre duas ou mais línguas, causando mudanças no português. De acordo com Gonçalves (1990, p. 89), a situação de língua segunda (L2) da LP em Moçambique "dá naturalmente origem a alterações às regras que regulam o seu uso na variante europeia", fazendo com que novos traços entrem na língua.

A língua não é apenas um meio de comunicação, é também um meio de manifestação de identidades por parte dos falantes, pelo fato de ela poder transportar valores culturais e étnicos de uma sociedade. Isso faz com que ela ganhe formas peculiares e que irão se diferenciar de outros falantes de outros contextos sociais, embora se tenha a mesma língua como meio de comunicação usado pelos diferentes grupos. De acordo com Aguilera (2008), a variedade linguística consiste em um traço definidor da identidade do grupo (etnia, povo) e, desse modo, qualquer atitude em relação aos grupos com determinada identidade pode tratar-se de uma reação às variedades usadas por esse grupo ou aos indivíduos usuários dessa variedade, uma vez que normas e marcas culturais dos falantes se transmitem ou se sedimentam por meio da língua, atualizada na fala de cada indivíduo.

Embora a LP seja a língua oficial, não se pode negar que ela seja influenciada por diferentes marcas do contexto em que ela está inserida, principalmente pelo fato de coabitar com diferentes línguas nacionais. Dela se espera, obviamente, de acordo com a natureza de cada língua em contato, que ganhe uma forma capaz de identificar os seus falantes no contexto geográfico da sua utilização. De acordo Firmino (2005, p. 67), "qualquer pessoa que fala a sua L1 é socialmente entendida como um forte indicador da sua identidade étnica"; ele avança com essa ideia pelo fato de, em Moçambique, o grupo linguístico coincidir com o grupo étnico.

A afirmação da identidade cultural de um povo passa pela sua afirmação linguística. Através da língua, valores, hábitos e costumes podem ser transmitidos de um indivíduo para o outro, ou de uma geração para outra, possibilitando a distinção 
entre membros de grupos culturais diferentes. Leray (2003, p. 120) afirma que "a língua é o primeiro vetor identitário que testemunha a diversidade sociolinguística nas comunidades humanas; a construção identitária não se restringe ao limite de um território mas inscreve-se numa história mestiça de línguas e de culturas". A própria língua já é um símbolo de identidade cultural, é um patrimônio cultural para além de ser o principal veículo de transmissão da cultura.

Moçambique, como já é sabido, é um país multilíngue, e impossível é falar de uma afirmação e desenvolvimento cultural nesse país relativamente às outras línguas, fora do português, o que não se verificava na ideologia do período colonial em que apenas o português era visto como língua, portanto, a única valorizada. Essa valorização irá reforçar a questão de identidade linguística dos falantes de todas as outras línguas do país, e um dos caminhos passa necessariamente pela educação, pela integração das suas línguas no ensino.

O processo de introdução das línguas nacionais no ensino em Moçambique teve início em 2003 abrangendo 14 escolas, e as estimativas oficiais apontam para a existência de 200 escolas em 2010, envolvendo 16 das cerca de 20 línguas bantu faladas no país (Gonçalves, 2012). Esta tendência crescente de ensino das línguas nacionais nas escolas públicas moçambicanas não só vai permitir ao aluno a fácil assimilação dos conteúdos, mas também resgata a valorização dos valores culturais de cada comunidade linguística. De acordo com Instituto Nacional de Desenvolvimento de Educação/Ministério de Educação (INDE/MINED, 2003, p. 127), "a introdução das línguas moçambicanas no ensino contribui para a valorização e manutenção da língua e da cultura bem como para o desenvolvimento da auto-estima, afirmação da sua identidade e atitude mais positiva em relação à escola". Ideia corroborada por Ngunga (2004, p. 5) ao afirmar que “....a padronização de Línguas Moçambicanas é um símbolo da vontade que nos move no sentido de cada vez mais assumirmos os contornos da nossa identidade histórica e cultural...”.

Em suma, constatamos que em Moçambique, assim como em África, há uma diversidade linguística, na sua maioria do grupo bantu. As outras LBm faladas em Moçambique, durante longos anos foram menos privilegiadas comparando-se ao português; no entanto, o português falado em cada região do país irá carregar marcas de identidade dos seus falantes, influenciado pela cultura e pelas suas línguas maternas. Essa influência é marcada também pelos empréstimos que as línguas bantu fazem ao português, como veremos na seção que se segue.

\section{Neologia e neologismos}

Nesta seção, traremos alguns conceitos ligados a neologismos, faremos menção aos empréstimos e estrangeirismos e aos casos de empréstimos das línguas 
bantu moçambicanas para o português. A evolução das línguas permite que o léxico esteja em constante transformação, fazendo com que haja renovação contínua, tendo em vista o preenchimento das necessidades internas dos falantes, num processo em que algumas unidades lexicais tornam-se arcaísmos devido ao seu desuso, e outras vão sendo criadas, o que culmina no enriquecimento do próprio léxico. Assim, de acordo com Martinet (1971), a evolução duma língua depende da evolução das necessidades comunicativas do grupo que a emprega. A sociedade pode moldar a língua de acordo com as suas necessidades comunicativas imediatas, e o poder de cada membro da sociedade em participar na criação de novas formas linguísticas; pelo menos, é assim como entende Baccega (2007), ao afirmar que

aprender a falar significa não apenas aprender a utilizar palavras que a sociedade nos entrega prontas, mas (deveria significar também) aprender a produzi-las. E aprender a produzi-las significa ter uma visão crítica da realidade em que se está inserido e, desse modo, participar do movimento rumo à construção de novas variáveis históricas (Baccega, 2007, p. 44).

O processo de criação lexical é denominado de neologia e a palavra que é criada neste processo denomina-se neologismo. Cabello (1991, p.323) explicita a distinção entre neologismo e neologia:

Cumpre ressaltar a diferença entre neologismo e neologia. Neologia lexical é a possibilidade de criação de novas unidades lexicais, em virtude das regras de produção incluídas no sistema lexical. Neologia é, pois, o fato e neologismo, o vocábulo, a criação vocabular nova.

Boulanger (1979, p.65-66) considera neologismo como sendo "uma unidade lexical de criação recente, uma nova acepção de uma palavra já existente, ou ainda, uma palavra recentemente emprestada de um sistema linguístico estrangeiro e aceito numa língua". Percebe-se, todavia, que só se tem neologismo quando uma nova palavra entra para a língua e que é adotada pelos falantes da língua sem criar problemas para as unidades lexicais existentes, isto é, permitindo que as diferentes unidades lexicais coexistam na mesma língua.

A formação de neologismos no português é muita antiga, podendo-se afirmar que vem desde os primórdios da sua existência. O léxico inicial do português vem do latim e a sua evolução foi se dando, com o andar dos tempos, por causa dos empréstimos de outras línguas, como é o caso do árabe, das línguas africanas e indígenas no Brasil, só para citar alguns exemplos; aliás, este processo de mudança acontece com qualquer língua. $O$ fato de a língua sempre renovar o seu léxico possibilita a entrada quase frequente de novos elementos e, atualmente, tem sido o inglês um dos maiores fornecedores desses elementos para LP. 
Barbosa (1996) denomina neologismo alogenético o item lexical trazido de outra língua, em oposição ao item lexical autóctone, emprestado no interior do próprio sistema linguístico (neologismo semântico ou conceptual) e assim o define:

\begin{abstract}
Deve-se distinguir, inicialmente, o empréstimo interno e o empréstimo externo de palavras. Para primeiro, entende-se como o movimento que se realiza entre vocabulários regionais, entre vocabulários profissionais, entre estes e aqueles ou, ainda, entre tais vocabulários e o vocabulário geral. O segundo refere-se ao empréstimo de um sistema lingüístico, integrante de uma macrossemiótica, faz de palavras de outro sistema lingüístico, pertencente a outra macrossemiótica (Barbosa, 1996, p. 290).
\end{abstract}

Esses dois tipos de empréstimos podem ocorrer dentro da mesma língua, principalmente para o caso de países como Moçambique, devido ao seu contexto multilíngue e geográfico, como veremos de seguida ao falarmos dos tipos de neologismos (fonológico, sintático e semântico) e dos empréstimos.

\title{
3.1. Neologismo Fonológico
}

De acordo com Alves (2007) e Barbosa (1996), este tipo de neologismo resulta da criação de um item lexical totalmente novo, sem base em nenhuma palavra existente. Alves (2007) usa a unidade lexical gás que tem sido interpretada como oriunda do étimo grego khaos, para exemplificar. Barbosa (1996) considera que o emprego de neologismos fonológicos como item lexical inédito é bastante raro. Para Barbosa, a produção onomatopeica específica é uma criação fonológica inédita e, "ocorre com menor frequência em todas as línguas, sendo mais comum em discursos literários" (Barbosa, 1996, p. 176). A onomatopeia resulta da criação de uma unidade lexical que tenha relação com certos sons ou gritos; ao que se pode entender que, em palavras onomatopeicas, existe sempre uma relação entre a palavra e o significante, como é o caso de "miau" em representação da voz do gato.

Em Moçambique, o neologismo fonológico vai ocorrer como resultado do contato entre a LP e as LBm. O processo pode ocorrer tanto na LP assim como nas línguas bantu, como podemos ver nos exemplos que se seguem, apresentados por Ngunga (2012) sobre o português e a língua changana (falada nas províncias do sul do país):
a. kuxatiyara (< chatear)
b. kuvota $(<$ votar $)$
c. manduwinya ( $<$ amendoim)

O que justifica os exemplos acima demonstrados é que, nas LBm, a sílaba tem, geralmente, a estrutura do tipo $(\mathrm{V}, \mathrm{CV}(\mathrm{V}))$. Para Ngunga, isto é, "exceptuando a nasal silábica, a única não aberta, a sílaba nas LBm é aberta, o que explica que os 
falantes destas línguas em geral e os das moçambicanas em particular, aprendendo a LP, revelem tendência de produzir sílabas abertas mesmos nos casos em que elas sejam fechadas na língua alvo" (Ngunga, 2012, p. 15).

Temos ainda os casos apresentados por Abdula (2014) em que os verbos do echúwabo $^{2}$ ao serem adaptados para o português recebem o acento tônico do português. $\mathrm{O}$ acento tônico no infinitivo verbal na LP encontra-se na última vogal do verbo (ex.: comer, falar, brincar, querer, sorrir, fingir, etc.), mas na língua echúwabo o acento tônico encontra-se na antepenúltima vogal. Quando os verbos do echúwabo passam para o português recebem o acento tônico do português (Abdula, 2014). Para este caso podemos ver os seguintes exemplos:

Loguelar (negociar) - ologela

Nhamelar (tirar proveito) - onyamela

Vundular (mexer) - ovunddula

Nhacuar (estar sujo) - onyakuwa

Tabutchar (fazer sofrer)- otabutxa

Gumular (destruir) - ogumula

Vedegular (revirar) - ovedegula

Roromelar (confiar em) - ororomela

Soquelar (contribuir)- osokela

Zuzumar (estar atrapalhado)- ozuzuma

\subsection{Neologismo Sintático}

De acordo com Alves (2007, p. 14), "ao contrário dos neologismos fonológicos, os neologismos sintáticos supõem a combinatória de elementos já existentes no sistema linguístico português". São denominados sintáticos porque a combinação de seus membros constituintes não está circunscrita exclusivamente ao âmbito lexical (junção de um afixo a uma base), mas concerne também ao nível frásico: o acréscimo de sufixos pode alterar a classe gramatical da palavra base, $\mathrm{e}$ a composição tem caráter coordenativo ou subordinativo.

Os neologismos sintáticos podem ser formados por: (a) Derivação prefixal: este tipo de derivação se forma quando é adicionada a uma base (radical) um prefixo, o qual the acrescenta uma grande variedade de significados. Ex.: Desconseguir $=\left[\mathbf{d e s}_{\text {pref }}+\right.$ conseg $\left._{\text {Rad }}+\mathrm{ir}_{\text {Suf }}\right]-$ não conseguir. Este exemplo embora não ocorra no português do Brasil por causa da não reversibilidade do verbo conse-

2. A língua echúwabo, segundo Guthrie (1971) apud Ngunga (2004), tem a classificação P34. O echúwabo é uma das línguas faladas na província da Zambézia, concretamente nos distritos de Maganja da Costa, Quelimane, Nicoadala, Namacurra, Inhassunge, Mocuba, Lugela, Mopeia, Morrumbala e Milange; e ainda na Beira, na Província de Sofala. 
guir, em Moçambique verifica-se a sua ocorrência; (a) Derivação sufixal: ocorre quando um sufixo é associado ao radical, o que, com frequência, altera-lhe a classe gramatical. Ex.: Loguelar [-loguel $\mathrm{Rad}_{\mathrm{Rad}}+\mathbf{a r}_{\mathrm{Su}}$ ] - negociar, como podemos ver nos exemplos apresentados por Abdula (2014), referentes ao contato entre o português e a língua echúwabo:

(i) "e como loguelavão..." -Loguel(a) (radical)+a (vogal temática)+vão Loguelar - do verbo ologela: interceder, implorar para, invocar para, suplicar para, negociar. Nesta frase loguelar corresponde a 'negociar'.

(ii) "Outros não querem soquelar ficam so a falar" -Soquel(a) (radical)+a (vogal temática)+r Soquelar - do verbo osokela: contribuir, angariar fundo, cobrar dinheiro pra algo que foi combinado. Nesta frase soquelar tem o sentido de 'contribuir'.

(iii) "Tentei até nos $300 \mathrm{mt}$, ele disse que estava a nhamelar da sua boa vontade" -nyamel(a) (radical)+a (vogal temática)+r Nyamelar - do verbo onyamela: seguir escondidamente para, aproveitar, tirar proveito de. Nesta frase nyamelar corresponde a 'aproveitar ou tirar proveito de'.

(iv) "Vocês vão lhe tatamular...". -tatamul(a) (radical)+a (vogal temática) $+\mathrm{r}$ Tatamular - do verbo otatamula: provocar, fazer sair do estado normal de tranquilidade, excitar, fazer explodir, exasperar. Nesta frase tatamular corresponde a 'provocar ou fazer sair do estado normal de tranquilidade'.

a) Composição: o processo de composição consiste na justaposição de bases dependentes ou não; isto é, os seus constituintes podem ser autônomos ou não autônomos e podem ser classificados como subordinativo ou coordenativo. Ex.: Chapa 100 - transporte semicoletivo de passageiros em Moçambique.

b) Composição sintagmática: também conhecido pelo seu aspecto morfossintático. É a sequência lexical, cuja ordem dos elementos constituintes é sempre a mesma: determinado seguido de determinante em que a união dos membros é de natureza sintática e semântica, de forma a constituírem uma unidade lexical. Ex.:

\section{Palavra-chave.}

c) Composição por siglas ou acronímica: É formada por meio de siglas ou acronímias, que têm a função de tornar o processo de comunicação mais simples e eficaz. Ex.: MICOA - Ministério para a Coordenação da Ação Ambiental.

\subsection{Neologismo Semântico}

De acordo com Barbosa (1996, p. 171), pode ser definido como empréstimo de significado, à medida que, em geral, não pressupõe alterações no significante. O neologismo semântico constitui-se de palavras já existentes, porém, utilizadas com novas acepções, ou seja, forma-se uma palavra por neologismo semântico 
quando se dá um novo significado, somado ao que já existe; trata-se do surgimento de uma significação nova para um mesmo segmento fonológico, que passa a ser uma nova unidade de significação. "Por meios dos processos estilísticos da metáfora, da metonímia, da sinédoque (...), vários significados podem ser atribuídos a uma base formal e transformam-na em novos itens lexicais" (Alves, 2007, p. 62). Por exemplo: a palavra cabrito significa 'fora da lei'; a esse significado somamos outro, '(corrupção) bom'; afinar, que em Moçambique pode ter o sentido de «usar português rebuscado»; o verbo alarmar usa-se indiferentemente para "pôr em alarme, assustar" e para «instalar alarme no carro»; emprestar significa não só "ceder temporariamente, conceder", mas também «pedir emprestado»; esquinar que corresponde a "desviar" e a "esperar na esquina"; estilar alarga o seu conteúdo a "exibir-se"; matabicho designa indiferentemente, "pequeno-almoço, gratificação, gorjeta"; mola estende o seu conteúdo semântico a "dinheiro". Segundo Carvalho (2009, p. 38-39):

Como sempre, necessidades novas são as causas mais frequentes para iniciar uma alteração semântica. Ao transitar de uma língua para outra, o novo termo quase nunca conserva a sua acepção inicial. Acrescenta outras conotações às suas de origem e por vezes subverte o significado. Isto porque mesmo que as significações de uma palavra procedam de seus usos passados, eles se modificam e se adaptam aos novos fatos permanentemente, apesar de os falantes não perceberem e crerem ser a língua uma unidade estática.

\subsection{Empréstimo e estrangeirismo}

A LP, como qualquer outra língua, sofre influências que podem ser um conjunto de incorporações que vêm de outras línguas. No entanto, existem vários níveis dessas incorporações. Dentre eles, temos os conceitos de estrangeirismo e de empréstimo, que, embora semelhantes, são fenômenos específicos e diferentes de incorporações de outras línguas, sendo o léxico o nível que sofre mais influências. Portanto, para melhor se compreender o fenômeno de empréstimo na LP é importante entender como esse fenômeno vem acontecendo. As múltiplas condições em que se tem processado o desenvolvimento da humanidade têm motivado, de maneira intensificada e (quase) inevitável, contatos e/ou cruzamentos, em diferentes níveis, entre variados povos e culturas, e, por consequência disso, ocorre a presença e a utilização de palavras e expressões importadas nas diversas línguas.

A este propósito, Cardoso (1991, p. 15) argumenta que “(...) têm sempre circunstâncias sociais, políticas e/ou econômicas que se colocam como instrumento promotor de trocas linguísticas, responsável, portanto, pela introdução de empréstimos". O empréstimo de acordo com Galisson e Coste pode ser entendido 
como sendo "um processo em que uma unidade lexical entra na língua acolhedora sem qualquer transformação" (Galisson; Coste, 1983, p. 228); todavia, não podemos afirmar de uma forma categórica que os empréstimos entram na língua acolhedora sem qualquer transformação, visto que eles podem sofrer transformações tendo em vista a adequar-se à estrutura fonológica e morfossintática da língua acolhedora. Pode-se afirmar que o empréstimo linguístico dá-se quando um falar usa e integra uma unidade ou traço linguístico que não existia antes. Segundo Sandmann, é "uma das formas de as línguas ampliarem seu estoque lexical” (Sandmann, 1997, p. 72).

Os empréstimos (lexicais) caracterizam-se pela incorporação por uma língua $\mathrm{X}$ (por exemplo, língua portuguesa) de unidades (lexicais) ou traços linguísticos existentes numa língua $\mathrm{Y}$ (língua echúwabo, por exemplo) e que a língua $\mathrm{X}$ não possuía. De acordo com Ngom (2000), há dois tipos de empréstimo linguístico no campo lexical. O primeiro caso seria quando o vocábulo incorporado em uma língua é reconhecido como um vocábulo estrangeiro, ou seja, os falantes percebem que determinado item lexical é originário de outra língua. Já o segundo tipo seria a completa incorporação do item lexical à língua que o está recebendo de modo que não há o reconhecimento da palavra como um vocábulo emprestado de outra língua. Nesse caso, a palavra torna-se natural para os falantes devido ao seu uso constante, sua ortografia e sua pronúncia similar a outras palavras da língua materna.

Sobre a integração do empréstimo ao léxico geral da língua, Barbosa (1996, p. 292) considera que "um termo só será considerado empréstimo propriamente dito, quando, numa fase ulterior à da adoção verdadeira pela integração e generalização, tiver alcançado alta freqüência e distribuição regular pelos falantes, a ponto de não ser mais sentido como estrangeiro". Temos os seguintes exemplos de empréstimos vindos do inglês que entraram na língua portuguesa: futebol, bife, nocaute. Por sua vez, o estrangeirismo pode ser entendido como sendo a utilização, de forma original, de uma palavra estrangeira à língua. Câmara Jr. define estrangeirismo como “(...) um empréstimo vocabular não integrado à língua que o toma, conservando das outras os fonemas, a flexão e a grafia, ou vocábulos nacionais empregados com a significação dos vocábulos estrangeiros de forma semelhante. Desta forma, o estrangeirismo não é adaptado à língua tomadora". (Câmara Jr. 2002 [1973], p.111)

De acordo com Bagno (2004, p. 74), "os estrangeirismos não alteram as estruturas da língua, a sua gramática", assim como acontece também com os empréstimos. A adaptação sintática é aquela que exprime uma mudança de classe. Portanto, é preciso criar uma nova palavra para designar essa função. Temos exemplos 
do estrangeirismo no português as palavras shopping, show e pizza que vêm do inglês.

Existem pessoas que são contra os empréstimos, principalmente em relação aos que se verificam na atualidade, que são empréstimos oriundos do inglês. De acordo com Crystal (2005), o que está a acontecer na verdade é uma mudança no caráter das línguas, influenciadas pela chegada de novos vínculos, como ele afirma - a escrita, o rádio, a televisão, a telefonia, a imprensa. Certamente estes instrumentos são novos tendo em conta a história da humanidade, e verificou-se, nos últimos anos, um desenvolvimento tecnológico bastante assinalável, e o produto desse desenvolvimento tecnológico é novo, senão estranho para a maioria dos povos. Sendo assim, não tem havido nomes apropriados para nomeá-los, e como eles já vêm com nomes das línguas que os fabricam, daí a necessidade de manter esses nomes; temos o caso de internet, facebook, shopping, entre outros, que vêm do inglês. O que Crystal (2005) encontra é um radicalismo das pessoas que se opõem à entrada desses nomes ingleses na língua; tais oposições podemos encontrar nos radicalistas franceses, e mesmo nos conservadores do português.

O que o autor nega não é que a língua seja preservada, mas é o fato de se querer controlar a "vida da língua", porque nenhuma língua é capaz de se fechar às mudanças e nenhum homem é capaz de controlar essas mudanças. Ele dá exemplo do próprio inglês, que tanto influencia atualmente as diversas línguas: se formos olhar o inglês falado hoje não é o mesmo falado na Idade Média, uma língua germânica que passou para uma língua de base latina e grega, o que significa dizer que o inglês também mudou. Isso não aconteceu só com o inglês, mas com várias outras línguas faladas no mundo que passaram pelo mesmo processo - é, portanto, um processo natural na evolução das línguas. Se o ser humano foi capaz de evoluir durante o tempo, os homens dos primórdios da humanidade não são os mesmos homens de hoje, vários processos se passaram, vários hábitos tiveram que ser alterados, no entanto, não podia ser a língua, que acompanha o homem em todos esses diferentes momentos, a se manter estática.

O que Crystal (2005) nega é essa falácia antiempréstimo. As línguas podem emprestar vocábulos que elas não têm e adaptá-los à sua realidade. O que ele sugere é que se tome maior atenção às línguas ameaçadas de extinção, pois, de acordo com suas palavras, das cerca de seis mil línguas no mundo, é provável que aproximadamente metade delas desapareçam no decurso deste século - em média uma língua morre a cada duas semanas. E esse é um problema na realidade, e não os empréstimos que têm acontecido, vindos principalmente do inglês.

Esta tentativa de travar o uso de empréstimos linguísticos tem criado oposição entre os gramáticos e os linguistas. Para os gramáticos, a língua deve ser ensinada 
e usada na sua forma padrão, a globalização descaracteriza a língua e isso pode levar à perda da identidade. Por sua vez, os linguistas defendem que os empréstimos não são prejudiciais, eles enriquecem o léxico; não pode haver descaracterização porque a gramática aborda sobre a morfologia, a sintaxe e a pronúncia destas palavras que entram na língua.

\section{Empréstimos de Línguas Bantu para o Português}

Segundo Calvet (2002, p. 36), "podemos distinguir três tipos de interferência: as interferências fônicas, as interferências sintáticas e as interferências lexicais". Para o autor, as interferências lexicais podem produzir os empréstimos, e os empréstimos só surgem quando uma determinada palavra não encontra o seu equivalente na língua, o que permite que a palavra pertencente à outra língua seja utilizada e adaptada à pronúncia da língua acolhedora. Mas esta não é a única razão que faz com que haja empréstimos, uma vez que os falantes recorrem aos empréstimos mesmo havendo equivalentes nas suas línguas. Calvet (2002) diferencia interferências de empréstimos; interferência é um fenômeno individual e empréstimo é um fenômeno coletivo.

Historicamente, sabe-se que o português recebeu empréstimos das línguas africanas, assim como de outras línguas, como o árabe. No contexto de Moçambique, em que o português encontra-se inserido no mesmo espaço que as línguas bantu, este fenômeno é ainda maior, devido à necessidade existente de usar o português por se tratar da língua oficial. Para Mendes (2010), a maior parte dos empréstimos provenientes das línguas bantu está associada à tradição e à cultura e, na sua maioria, servem para designar pratos tradicionais, frutos e plantas moçambicanas, animais, danças moçambicanas, etnias, danças e rituais tradicionais.

Temos os exemplos de maconde - um grupo étnico da Província de Cabo Delgado; nyambaro - uma dança tradicional da província da Zambézia; lobolo - casamento tradicional na região sul do país; mukutto - um ritual tradicional na província da Zambézia. Essa influência será marcada de acordo com a língua de contacto que o português tiver em cada região do país, fora as palavras que são quase comuns para muitas línguas moçambicanas como é o caso de mahala que significa "grátis" em português; esta palavra denomina a mesma coisa em muitas línguas moçambicanas, o que faz com que seja mais usada que a palavra "grátis". Para além dos casos anteriormente mencionados em que os empréstimos ocorrem, verifica-se também o empréstimo na formação de verbos em português, mas com radical das línguas bantu. Debruçando-se sobre o contexto de Moçambique, no que diz respeito às causas dos empréstimos das línguas bantu, Dias (1990, p. 100) aponta os seguintes fatores: 
1.Preenchimento de uma lacuna no léxico da língua portuguesa, quando a realidade a ser referida julga-se inexistente em Portugal, como é o caso de nomes de frutos, comidas e costumes; 2.Preenchimento de uma lacuna no conhecimento da língua portuguesa. Estes são introduzidos por falantes numa fase inicial de aprendizagem da língua portuguesa; 3.Identificação sociocultural entre os falantes (...). Este fato pode ser explicado tendo em conta a situação de diglossia existente em Moçambique pelo estatuto de que o português goza.

Dos neologismos registrados no Observatório de Neologismo do Português de Moçambique (2013), 29.8\% são formados por sufixação, 21.5\% são empréstimos, $14.2 \%$ são formados por composição, $8.9 \%$ por prefixação e $8.6 \%$ são neologismos semânticos. Portanto, de acordo com estes dados, a derivação por sufixação é o processo lexical mais produtivo no Português de Moçambique.

\subsection{Casos de hibridismo}

Assim como os empréstimos, os hibridismos só terão lugar numa situação em que teremos em cena mais de uma língua, não havendo espaço para que se fale em situações em que apenas uma língua determina os constituintes dentro da palavra. Sendo assim, pode-se entender por hibridismo o processo de formação de palavras a partir de elementos pertencentes a duas línguas diferentes. Kehdi (2007, p. 50) diz que hibridismo "é a designação dada aos vocábulos compostos ou derivados, cujos elementos provêm de línguas diferentes". Desta afirmação entende-se que o hibridismo pode acontecer em casos de palavras formadas por derivação e composição, por exemplo, nas seguintes combinações do português: autoclave - auto (grego) + clave (latim); burocracia - buro (francês) + cracia (grego); monocultura - mono (grego) + cultura (latim).

Cunha e Cintra (1990, p. 115) chamam de unidades híbridas “...aquelas que se formam de elementos tirados de línguas diferentes". Com esta passagem, compreende-se que a posição que cada elemento irá ocupar na composição da nova estrutura não determinará a sua consideração como híbrida ou não, o que interessa é que elas tenham vindo de duas línguas diferentes. Dubois et al (1989, p. 256) considera o hibridismo como sendo "...uma unidade composta em que os constituintes são emprestados a radicais de línguas diferentes”. Esta definição foi questionada por Mendes (2010), no que concerne à sua aplicabilidade nas construções neológicas híbridas mais frequentes que ocorrem no Português de Moçambique, e ela pode induzir ao erro pelo fato de referenciar apenas o processo de formação por composição deixando de fora a derivação, uma vez que, no Português de Moçambique, o hibridismo é um processo de formação que recorre com mais frequência à derivação. 
De acordo com Mendes (2010, p. 158), a maioria das formas híbridas em Moçambique pertence à classe de nomes e de verbos. Estas formas podem ser constituídas a partir de: a) morfemas prefixais das línguas bantu, associados à base portuguesa; b) uma base lexical de Línguas Moçambicanas, na qual se anexam morfemas portugueses (geralmente sufixos), seguindo o processo de derivação de unidades lexicais da gramática portuguesa; e c) uma base inglesa ou de outra língua na qual se juntam sufixos ou desinência verbal portuguesa.

Se o hibridismo pode ser entendido como sendo o processo de formação de palavras a partir de elementos pertencentes a duas línguas diferentes, o empréstimo é "uma forma resultante de uma única língua estrangeira com ou sem transformação" (Mendes, 2010, p.167). É nesta perspectiva que os dois conceitos vão se diferenciar. Desta seção, podemos compreender que todas as línguas do mundo fazem empréstimos de outros sistemas linguísticos para dar conta de novos elementos que vão entrando para as línguas. Certas vezes, esses empréstimos sofrem adaptações ou passam por uma formação híbrida; isso pode ser visto, no caso de Moçambique, onde encontramos formações que resultam de empréstimos de línguas bantu para o português, sendo na maioria dos casos verbos.

\section{Considerações finais}

Moçambique um país jovem e a história da LP em Moçambique também é jovem. Antes da independência, o número de falantes de LP era muito reduzido e o cenário mudou com o alcance da independência em que houve um crescimento bastante significativo de falantes. Se no período antes da independência houve aumento do número de falantes do português devido à política de colonização massiva, no período pós-independência houve aumento de falantes do português devido à política de massificação da língua portuguesa e da pré-disposição da população moçambicana a adotar o português como língua de comunicação em detrimento das línguas bantu.

Apesar de haver um número cada vez mais crescentes de falantes de língua portuguesa em Moçambique, é preciso compreender que o país possui mais de vinte línguas e, a maioria delas, do grupo linguístico bantu. Por causa da existência dessas línguas e por habitarem no mesmo espaço geográfico que a LP, o contato é inevitável; muitos moçambicanos que falam o português também falam uma ou várias outras línguas moçambicanas. Nem todo o aluno que fala o português na escola usa a mesma língua para se comunicar em casa com os seus familiares, amigos ou a comunidade onde reside, sobretudo na zona rural. Por outro lado, existem moçambicanos que têm o português como língua materna e moçambicanos que falam apenas a LP, embora seja um número reduzido se comparado 
com a tendência da maior parte da população. Mas esse número tende a crescer e a equilibrar-se, principalmente na zona urbana onde o português é mais falado.

Como impacto do contato entre o português e as línguas bantu, verifica-se uma influêcia mútua entre esses dois grupos linguísticos com destaque para o português, em que o aumento de casos de moçambicanismos resultantes de neologismos e empréstimos que o português faz das línguas bantu. Por via disso, o Português de Moçambique vai ganhando novas feições e vai criando uma identidade própria. Os neologismos e os empréstimos são uma marca de identidade do português de Moçambique. Há influências das línguas bantu sobre o português em níveis como o fonético, fonológico, lexical. Porém, a maior parte dos empréstimos provenientes das línguas bantu são lexicais e está associada à tradição e à cultura e, na sua maioria, servem para designar pratos tradicionais, frutos e plantas moçambicanas, animais, danças moçambicanas, etnias, danças e rituais tradicionais.

\section{Referências}

Abdula, Rajabo Alfredo Mugabo. Marcas de influência do echúwabo no português de Moçambique: a questão dos verbos nas redes sociais. 2014, 117p. (Dissertação de Mestrado), Faculdade de Ciências e Letras, Universidade Estadual Paulista, Araraquara. 2014.

Aguilera, Vanderci de Andrade. Crenças e atitudes linguísticas: o que dizem os falantes das capitais brasileiras. Estudos Linguísticos. São Paulo, v. 37, $n^{\circ} 2$ p. 105-112, 2008. Disponível em: <http:// www.gel.org.br/estudoslinguisticos/volumes/37/EL_V37N2_11.pdf $>$. Acesso em: 12 set. 2012.

Alves, Ieda Maria. Neologismo: criação lexical. 3.ed. São Paulo: Ática, 2007.

Baccega, Maria Aparecida. Palavra e discurso: história e literatura. São Paulo: Ática, 2007.

Bagno, Marcos. Cassandra, fênix e outros mitos. In: Faraco, Carlos Alberto. (Org.). Estrangeirismos: guerra em torno da língua. São Paulo: Parábola, 2004. p. 47-83.

Barbosa, Maria. Aparecida. Léxico, produção e criatividade. São Paulo: Plêiade, 1996.

Boulanger, Jean-Claude. L'évolution du concept de neologie de la linguistique aux industries de la langue. In: Schaetzen, Caroline de. (Org.) Terminologie anachronique. Paris: Conseil Internacional de la Langue Française, 1989, p.193-211.

Cabello, Ana Rosa. Gomes. Gíria e neologismo: convergências e divergências. Anais do XXXVIII Seminário do GEL, Franca-SP: UNIFRAN, p. 229-332, 1991.

Câmara Jr. Joaquim Mattoso. Dicionário de linguística e gramática. Petrópolis: Vozes, 1981.

Calvet, Louis-Jean. Sociolinguística: uma introdução crítica. São Paulo: Parábola, 2002.

Cardoso, Suzana Alice Marcelino. Empréstimos: uma questão linguística e/ou político-cultural? Revista Internacional de Lingua Portuguesa. nº 5/6, p. 9-17, 1991.

Carvalho, Nelly. Empréstimos linguísticos na língua portuguesa. São Paulo: Cortez, 2009.

Crystal, David. A revolução da linguagem. Rio de Janeiro: Jorge Zahar, 2005. 
Cunha, Celso; Cintra, Lindley. Nova gramática do português contemporâneo. 7ed., Lisboa: João Sá da Costa, 1990.

Dias, Hildizina Norberto. Línguas e mudanças sociais: algumas reflexões sobre o caso de Moçambique. Revista Internacional de Lingua Portuguesa, no 8, p. 96-100, 1990.

Firmino, Gregório. A questão linguística na África pós-colonial: o caso do português e das línguas autóctones em Moçambique. Maputo: Promédia, 2005.

Galisson, Robert; Coste, Daniel. Dicionário de didática das línguas. Coimbra: Livraria Almedina. 1983

Gonçalves, Perpétua. Lusofonia em Moçambique: com ou sem glotofagia? Comunicação apresentada no II Congresso Internacional de Linguística Histórica. Homenagem a Ataliba Teixeira de Castilho. São Paulo. 2012.

Gonçalves, Perpétua. (Dados para a) história da língua portuguesa em Moçambique. 2000. Disponível em: <http://www.institutocamoes.pt/CVC/hlp/geografia/portuguesmocambique.pdf>. Acesso em: 13 abr. de 20117.

Gonçalves, Perpétua. A construção de uma gramática do português em Moçambique: aspectos da estrutura argumental dos verbos. Tese de Doutoramento, Universidade de Lisboa. 1990.

INDE/MINED. Programas das disciplinas do $3^{\circ}$ Ciclo: Ensino Básico. Maputo: Academia Lda, 2003.

Kehdi, Valter. Formação de palavras em português. 4ed., São Paulo: Ática, 2007.

Leray, Christian. A Língua como Vetor Identitário: o caso particular do gaulês na Bretanha. In: Coracini, Maria José. (Org.). Identidade e discurso. Campinas: Ed. Universitária Argos, 2003. p. 119-136.

Martinet, André. Elementos de linguística geral. Rio de Janeiro: Martins Fontes, 1971.

Mendes, Irene. Da neologia ao dicionário: o caso do Português de Moçambique. Maputo: Texto Editores, 2010.

Namburete, Eduardo. Língua e lusofonia: A Identidade dos que não Falam Português. in: Bastos, Neusa Maria. (Org.) Lingua portuguesa: reflexões lusófonas. São Paulo; PUC-EDUC. 2006. p.63-74.

Ngom, Fallou. Sociolinguistic motivatons of lexical borrowings in Senegal. 2000. Disponível em: <http://www.ideals.illinois.edu/bitstream/handle/2142/9657/SLS2000v30.2-10Ngom. pdf? sequence=2>. Acesso em: 13 abr. 2017.

Ngunga, Armindo. Interferências de línguas moçambicanas em português falado em Moçambique. 2012. Disponível em: <http://www.revistacientifica.uem.mz/index.php/seriec/article/ view/15/28>. Acesso em: 13 abr. 2017.

Ngunga, Armindo. Introdução à Linguística Bantu. Maputo: Imprensa universitária, 2004.

Sandmann, Antônio José. Morfologia lexical. São Paulo: Contexto, 1997.

Silva Neto, Serafim da. História da língua portuguesa. Rio de Janeiro. Presença Edições, 1988. 